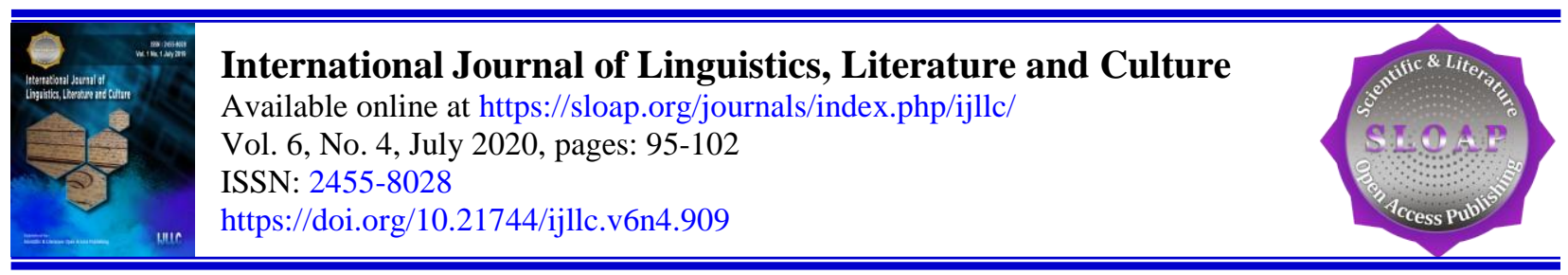

\title{
Representation of Iraqi Prisoners' Abuse in Judith Thompson's Palace of the end: A Politico-Cultural Perspective
}

Salih M. Hameed a

Article history:

Submitted: 18 April 2020

Accepted: 09 May 2020

\section{Keywords:}

a politico-cultural perspective;

Iraqi prisoners;

representation;

systematic abuse;

\begin{abstract}
The paper is a study in the representation of the systematic abuse inflicted by the American Female Soldier (being an image of American militarism) upon the Iraqi prisoners in the Abu Ghraib jail. The American misconducts exercised are based on political and cultural grounds: it is dramatically evident that the American Female Soldier has prejudicially transformed the stage into a battleground, whereon, post colonially, the Iraqi prisoners are viciously addressed by demeaning terms.
\end{abstract}

International journal of linguistics, literature and culture (๐) 2020.

This is an open access article under the CC BY-NC-ND license.

Peer-review under responsibility of International Association for

Technology, Education and Language Studies (IATELS) (https://creativecommons.org/licenses/by-nc-nd/4.0/).

\section{Corresponding author:}

Salih M. Hameed,

College of Arts, Ahlul Bait University, Iraq.

Email address: salih_mahdy@yahoo.ca 


\section{Introduction}

In American Psycho, Bert Easton Ellis contemplates if 'evil' "is something one is, or if it "is something] one does] ."b Whether or not it is the 'nature' or the 'nurture' of the human psyche, it indeed makes no difference: for Ellis, it is the same 'mental disorder' that renders the case akin to bipolar, obsessive-compulsive disorder or any other psychosis issue. To humanity dismay, it is, nevertheless, untreatable, for, in Ellis's words, "[t]herapy and meds are ineffective. The only solution is to wait until a serious felony is committed, then they . . . can be diagnosed and locked; otherwise, the people around them would often suffer wraths of these individuals."

The resulting impact of such disorders is unquestionably constant pain severely inflicted upon victims irrespective of what rationalizations they indeed offer; nonetheless, the guiltless subjects gain no more knowledge as to what misdeeds or misdemeanors they have committed, hence emerges neither catharsis nor new understanding. However, they even turn out to be so helpless and vulnerable that they find no reason to tell of their pain. As long as they grow voiceless, it is, therefore, the reason why they often expect someone else to undertake to ring out their grieves and agonies. These are certainly the voices of artists whose concerns and obligations always invite them to utilize their voices on behalf of the voiceless. And dramatists are sincerely not an exception.

The abuse inflicted upon the Iraqi prisoners at Abu Ghraib Jail was held back behind the scenes for a time until it was publicly exposed to the world through the photos widely put on view. Arts, media, and drama have equally contributed to the worldwide expostulation of the abuse of, and violence against, the Iraqis. Like such playwrights as David Hare, Rajiv Joseph, Lydia Stryk and others, Judith Thompson has embarked on dramatizing the US war on Iraq in her Palace of the End, the opening scene of which is impressively devoted to the US soldiers' abuse of the Iraqi prisoners at Abu Ghraib Jail.

\section{Materials and Methods}

a) The approach of the American Soldier's abuse makes interesting use of postcolonial theories, that always consider the 'other' both lesser and inferior.

b) The paper resorts to elaborately analyze the means of enforcing American 'unicultuarlism' on Iraqi cultural modes by politico-military ways.

c) The study is based on detailed critical assessments and investigation of the soldier's character, and her personal (as well as the army's) perseverance to demean the Iraqi cultural identity.

\section{Results and Discussions}

\subsection{Results}

a) The study clearly shows that the Female Soldier's abuse does not represent her misconduct, but it is indeed the American common unconscious: the martial sentence enforced upon her and her fellow soldier is only a cover to veil the authorities' roles.

b) It is doubtless that the US Administration and militarism have potentially exploited the post $9 / 11$ popular moods to seek refuge for their demeaning acts.

c) The paper displays that the soldier is quite aware of the significant roles of Iraqi cultural modes in identifying the Iraqi character.

\subsection{Discussion}

Palace of the End is indeed a play wholly devoted to three distinct experiences implemented by three apparently different, but organically interrelated figures representing three perspectives of the reality of the US-Iraq war: they are the American female SOLDIER penalized for misconduct and abuse of the Iraqi prisoners in Abu Ghraib Jail, the British Weapon Inspector knew for his 'false' information about Weapons of Mass Destruction (WMD) in Iraq, and an Iraqi mother whose life was destroyed twice; first by Saddam's detectives and, eventually, by the Americans who

${ }^{\mathrm{b}}$ Bret Easton Ellis. American Psycho. (N. Y.: Random House Digital, Inc., 1991.) 
invaded the country. Thompson's is a play of three voices that finally harmonize to constitute the 'make' of the drama. Even though one drama critic considers Palace of the End a 'docudrama', the dramatist herself frankly admits in one statement that each of the three monologues is inspired by "news, stories or reach on real events, yet, interestingly enough, the character in each monologue "has been created by me, and everything other than the real events springs from my imagination."c

In her portrayal of the three characters Thompson's interest in, and fascination with, the human psyche is prominently impressive: in fact, it is enhanced by her and her family's occupation with psychology and Freudian psychoanalysis, as well as by her expertise in drama and dramaturgy. Like her early plays, Palace of the End equally exhibits an insightful quest for the drives that operate within the psyche, other than for the profound understanding of the 'invisible' that might guide the human impulses. The play, however, undertakes to seek both the actual innate forces and the physical powers that provoke conducts and/or actions one character experiences. Thompson's disgraceful female SOLDIER, David Kelly, and Nehrjas are presented not only as "historical figures" whose roles in real anecdotes are universally acknowledged, but also as "clients" where the playwright re-formulates their human structures and re-familiarizes the insights that display them unlike what they most likely are. Thompson's reformulation and re-familiarization is the playwright-as-psychiatrist's search for the genuine motives of change that are subtly beheld only by the keen eyes that seek out the 'unsaid' amid mind's anarchy. ${ }^{\mathrm{d}}$

Thompson's triptych of monologues conspicuously displays the wide-ranging disparity between the truth of people in reality when beset by anarchy and disarray, and the aestheticism and orderliness of art reflected by her dramatic personas. The persons do not render only their life anarchic, but also all the world around them vile and uglylooking; whereas the 'art' personas aesthetically foreground the graces of creativity and attraction.

Even though Palace of the End creates an example of "revisionary intervening space through a triptych of . . . monologues connecting disparate stories in a complex rendering of the local and the global dimensions of the Iraq war," yet Thompson characteristically and aesthetically blends the "masculinized, sexualized, racialized and classed dynamics" through which the war events operate, ${ }^{\mathrm{e}}$ for the three characters are presented on the stage whilst probing their 'interiority' of 'individual' experiences about the US and UK presence in Iraq. David Kelley's and Nehrjas's recollections are mere personal experiences that have brought about universal outcomes; the American female SOLDIER, notwithstanding, displays more "institutionalized mechanisms of violence" wherein the 'unconscious' and the 'person' are inseparable from the politico-cultural frames of mind, a topic with which this paper mainly deals.

The American female SOLDIER indeed represents in both word and action the responses of the US "institutions, discourses and ideologies" that disclose the social unconscious of the US politics "in moments of crisis as well as moments of reflection." The playwright's gendering of militarization and political coercion underlies multifaceted potential significance: it does not only display a horrid degree of torture but profoundly unveils the "cracks and fissures in the psyches"f as well as the marked failure of ethos and militarism. The American female Soldier seems to have been allotted gender reassessments that correspond with her politically ideologicalized roles. Dramatically speaking, Thompson's interest in the American female SOLDIER's abuse of the Iraqi prisoners in Abu Ghraib Jail lies in her awareness that art, in general, and drama, is a communal art, in particular, are expected to voice the most valorous thoughts of, and protest against, whatever might degrade man and endanger his/her humanity. It is indeed the arena where political theatre potently operates: it is, however, not the time to focus social movements per se, but to vigorously broaden the scales wherein theatre maneuvers, like issues of Civil and Human Rights, Peace Settlements and in Jenny Spencer's words, all "community-based gestures. ${ }^{\text {g }}$ Hence, such drama does not merely present a critique of government violation of civil and human rights, but also frank protest against the disgraceful coercion of soldiers and militarism.

c Kenneth Jones, "Judith Thompson's Palace of the End Looks at the Iraq War," PlayBell, January 14, 2008; accessed on March 21,2019 . Besides, in an e-mail sent by the playwright to the author as an answer to a question related to her information about Nehrjas's character, Thompson writes: "My Iraqi friend translated the account of the persecutions of Nehrjas and her family from an Arabic book - I listened carefully and then went home and wrote the monologue - creating the character myself, from an instinctive feel, but making sure the details were as they were in the book." E-mail to the author on Sept.13, $2016 ; 4: 30$ p.m.

d Sharon Friedman, "The Politicians and the Mass Media in Contemporary Theatre of War by Women," Theatre Journal, Vol. 62, No. 4. 602.

e Ibid.603.

f Ibid.

g Jenny Spencer, "Political and Protest Theatre after 9/11: Patriotic Dissent," Theatre Topics, John Hopkins University Press, Vol. 24, No. 2, 2014. 160.

Hameed, S. M. (2020). Representation of Iraqi prisoners' abuse in Judith Thompson's palace of the end: a politicocultural perspective. International Journal of Linguistics, Literature and Culture, 6(4), 95-102. https://doi.org/10.21744/ijllc.v6n4.909 
Most consciously and systematically than none, the American female SOLDIER seems to have exchanged the prison for the battlefield. And accordingly, she has dealt with the Iraqi prisoners. Reverberating George Bush's dictum and colonizers' theorems of what the 'others' are, she describes the Iraqi prisoners in Abu Ghraib Jail as "APES" and

monsters in the shape of human beings. They were prisoners

of WAR, [and ] TERRORISTS, guys who had KILLED AMERICAN

GUYS WHO WERE PLANNING ANOTHER 9/11, dude,

AND YOU ARE UPSET THAT I laughed AT Their WILLIES?"

$(P E, 17-18)^{\mathrm{h}}$

The swearing words and the 'low' slang language used by the American female SOLDIER emphasize the colonizers' assumption that the colonized are solely lesser and inferior; they are also considered 'animals' as well: therefore, they deserve to be dominated and taken over both physically and intellectually. This is, however, accompanied by a "planned psychological depreciation of the [colonized's] self-worth and of [his] culture and history."i The American female SOLDIER is quite aware of how disrespectful it is to laugh at men's 'privates'; but given the fact that the Iraqi prisoners are only 'others', and as a colonizer, she does that humiliation mainly to "get to the intelligence and that according to their culture, me laughing at their willies was worse than beatin way worse." (PE, 15)

Most likely, the American female SOLDIER resorts to act like that and use the 'low' military slang language as, in Terry Eagleton's words, the "profit motive which impels culture to spread its way across the globe." $\mathrm{j}$ As a type of the colonizer's motives and ideology, the American female SOLDIER's insistence on the use of such language and conducts might stand for the colonizer's embedded drives of 'expansionist ambitions' of the new US capitalist system of "America First!" Such a culture has dispersed as a colonizing phenomenon that exercises its turn. In this sense, it seems that US capitalism has employed the prominent role of 'power' to "testify to the emergence of an aesthetic form of capitalism"ktransmitting from the material to the immaterial.

In this sense, however, the American female SOLDIER's monologue systematically exemplifies what Eagleton calls the "concept of distinction." This is indeed one 'social unconscious' mechanism of the new American 'advanced Capitalism' whose principal aim is to "preserve inequality". The American female SOLDIER conceitedly confesses that when once she went to the church to think upon her sin, she saw her old friend Lee Ann Wibby. The latter turned around her and looked at her and soon the American female SOLDIER "knew then, that what all happened at the clubhouse had been more than a joke for her." Hence, with all her heart she "did pray for forgiveness about Lee Ann Wibby -" for the misconduct she did a long time ago. But she 'does not pray for forgiveness' about the Iraqi prisoners, because "Lee Ann Wibby is an American, she was VERY different from the APES AT ABU GHRAIB." $(P E, 17)$

Such material inequality between the Americans and the Iraqis is continuously maintained through all the US arm's conducts, echoing the concept that the Americans regard themselves as racially superior to the Iraqis as well as all the 'others.': this concept is politically and militarily enhanced by their "control over an oil-rich region they have

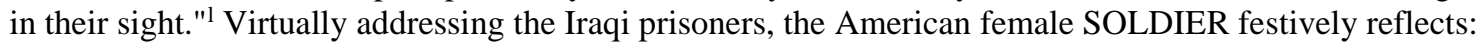

\footnotetext{
$\mathrm{h}$ Judith Thompson. Palace of the End. (London: Oberon Books, 2010.) Henceforth, all references to the play are taken from this edition and will be parenthetically cited within the text as $(P E)$ followed by page number.

${ }^{\mathrm{i}}$ Raad Kareem Abd-Aun, "The Representation of the Other in Postcolonial Drama: A Comparative Study in Selected Postcolonial Plays in English and Arabic," An Unpublished PhD Dissertation, College of Arts, University of Baghdad, 2011. 15.

j Terry Eagleton. Culture. (Yale: Y. U. P., 2016. 151.)

k Ibid.

${ }^{1}$ Eagleton, 155-6.
} 
I'm buzzin you down 'til you ain't got shit left 'til you

ain't even human. And then I mona take you down further.

And then, when we good and ready, we blow your brains out.

And we laugh while we are doing it. Make no mistake.

Because we are rejoicing.

In defeating. The enemy.

Of freedom. (PE, 19-20)

Although the American female SOLDIER speaks the language of gender, identity, and militarism, she relies on the difference between colonialism and anti-colonialism, which is, in Lacan's words, the difference between the "[O]ther and the [o]ther."m In the Social Unconscious, the American female SOLDIER justifies all her, and the army's, misconduct in terms of politics, power, and 'War on Terror.' She professes that "we were not entertaining ourselves. We were breaking down the terrorists. And it worked. We did attain information." $(P E$, 16). And during her entertaining misconduct, she never forgets the "Twin Towers and all the people running." $(P E, 19)$ And, finally the so-called 'War on Terror' which Eagleton describes as "persistence of cultural questions in political society . . . . [whence] the collapse of the World Trade Center [is seen] as a surreal explosion of archaic cultural forces at the very heart of modern civilization." More obviously than ever, here lies the clash between the fake American 'multiculturalism' and the actual insistence upon the enforcement of their uniculturalism. War and violence categorically illustrate and employ the American female SOLDIER's monologue as cultural aspects of colonizing strategies to invalidate the Iraqi identity by the death of culture.

The American female SOLDIER voices the US militarism as well as the American social unconscious in respect of responses to the 'others'. Even though in Freud's views, she could be sick of self-blindness and some defensive saving amnesia which she must have utilized to 'flourish'; she might equally identify the self-reflections of the American military and the US media-celebrated social-unconscious. The US colonizers seem to have fully held what they viewed as 'convictions', that the Iraqi prisoners are 'terrorists', hence enemies to the US, and 'inferior' to the Americans. This could certainly explain why the American female SOLDIER is convinced of replacing the prison for the battleground. She is self-aware that the disclosure of military confidential acts and invisible details of everyday activities in Abu Ghraib Jail is part of war schemes. This explains why she must be fully 'seen' rejoicing and laughing, for it is a military strategy: "I had a smile on my face but this was SERIOUS-INTELLIGENCE WORK" $(P E .15)$ whose basic aim is to break down the enemies!

The acts of humiliation exercised against the Iraqi prisoners are not haphazardly or arbitrarily conducted, but they are perfectly well-planned physically, politically, and culturally. The American female SOLDIER shows marked knowledge of culture-awareness about the Iraqi identity and mentalities. It must be purposeful that she commences with the prisoners who reveal protest and objection to both the US invasion of Iraq and the American conducts and uniculturalism. She deliberately begins with one prisoner who knows "little English", only because he has called her a dog; a matter that invites her to "fuckin give it to him", for instantly she has decided to take "the guy around on a leash", cynically reflecting: "You think I'm a dog? You think I'm a fuckin dog, you monkey fuckin let's go for a fuckin walk you wanna go for a walk" (PE, 16) The American female SOLDIER is aware of the religio-cultural bearings as well as the material and immaterial meaning of female figure "leashing" a man publicly with his colonizers laughing and rejoicing. The other soldiers' sharing the derision and entertainment reinforces the likelihood that such conducts imply a collective army 'strategy'; for she brags that her army fellows have seen her "tough": she, nevertheless, hilariously reveals that she "was as tough and as bad and as bad-assed as they were." (PE, 19) This identification of the 'feminine' with the 'masculine' underscores the unanimous objective of the whole act; for soon, she concludes that as a little girl from West Virginia, she "wouldn't afraid of no Saddamite."!

This conduct that she has considered a mark of notable success seems to have tempted the American female SOLDIER to pursue more aggressive and demeaning acts of abuse. Out of the US army's self-blinding pretext that the Iraqi prisoners are 'terrorist' and 'enemies', they are encouraged to filthily exaggerate their acts of defamation, targeting more prisoners much more aggressively. The American female SOLDIER could not miss the opportunity of what she regards as her 'victory', for, on the spot, she gleans the harvest: the little "ugly" girl of West Virginia is happily encountered by a "cute guy [having] a woody for [her ]." She says she could not believe him addressing her

\footnotetext{
${ }^{\mathrm{m}}$ Cited in Dylan Evans. An Introductory Dictionary of Lacanian Psychoanalysis. (London and New York: Routledge, 1996$), 135$. For more details, see: Raad, 8-12.

${ }^{\mathrm{n}}$ Eagleton, 161.
}

Hameed, S. M. (2020). Representation of Iraqi prisoners' abuse in Judith Thompson's palace of the end: a politicocultural perspective. International Journal of Linguistics, Literature and Culture, 6(4), 95-102. https://doi.org/10.21744/ijllc.v6n4.909 
as "Private Sex" giving her such a "wicked smile [that makes her] melt. . . doing it up down and sideways, yes, sometimes in front of the RAKEES. Just to fuck 'em up." $(P E, 20)$

As colonizers, the army people are aware of the religio-cultural implications of publicly making sex: they certainly understand that the obscene scene must be inappropriate for the Iraqi prisoners who would certainly not like to watch it: for the Iraqis, the scene is not only rude and disgusting but socio-culturally demeaning. Determined to 'force' the Iraqi prisoners watch the live porn obscene scene, The US soldiers are keen on seeking all means to oblige the Iraqi prisoners to watch the couple whilst making sex. They must very much understand that the public sex scene is insulting to the moral codes and identity of the Iraqis. The conduct might be viewed as the self-determined imposition of the Western culture on the Iraqi cultural domains. Such enforcement of unicultural wills is witnessed as a "privileged status" wherein the action is transmitted to a 'dramatic performance' where the sex act is not identical with its actual meaning for the 'Other' as much as with its politico-cultural meaning for the 'other.' Nonetheless, although the action occurs in one place (in this sense: Abu Ghraib Jail), its meaning is another: it is the battlefront. This explains why they are determined that the Iraqi prisoners should watch the scene even if perforce. And it, however, justifies why the US soldiers are more fully resolved to pursue their violent abuse much more offensively.

On the trail of the same strategy, the American female SOLDIER pompously reports to the audience what the US soldiers' next rejoicing sport is. Again the victims are not indiscriminately chosen: there is emphatically a religiopolitical aim of much more significance than merely a public abuse:

One of 'em, who the other ones seem to look up to? I

think he was like a holy man. Ronnie goes to him: "Hey

you. Wise Man. Mullah. Fuck him, fuck your friend

there in the butt, man. Do it now." (PE, 21)

And straightaway, the Iraqi prisoner reflects that "there is no reason for this. This I will not do for your entertainment." And when the prisoner refuses to abide by Ronnie's command, the latter is infuriated and gets so mad that he "had a take a shit so he takes it right there in a bucket hands it to the man, the guy who spoke English, and Ronnie makes him . . . eat his shit! He starts shooting at his feet. "Eat it, eat it, teacher." So he eats . . . . Ronnie's shit and that shit stink, dude."(ibid.) It is needless to say that such misconduct is too indecent to be human. The interpretation of such behavior serves to confirm that it is never a matter of fun. Politically speaking, it seems to be taken for granted that the senior Army people will not regard it as a violation of ethos, nor is it ever likely viewed as a breach of Human Rights or Prisoners of War ethics: it is, however, more a badge of ideology that disguises the actual objectives. What the US soldiers do is at odds with what they propagate and say they do. Such misconducts and politico-culturally oriented ideology cannot (and should never) be considered individual incidents: they certainly fall within the domain of 'business' that maintains 'political power' and serves to win personal gains.

\section{Conclusion}

Irrespective of the individually personal motives that have driven the American female SOLDIER to defame the Iraqi prisoners and underestimate their moral and cultural values, her misconducts equally represent the Western collective social unconscious which considers the Iraqis as both 'others' and, therefore, inferior: the colonizers are, however, politically and culturally aware of the inequality between the 'Other' who is only the image they see in the mirror when they look at themselves, and the 'other' who is not themselves! For the Americans, it seems that such an understatement of the Iraqis does not necessarily require any justification. But, fortunately, such abuse and violence are heavily decried and denounced by the artists and intellectuals.

In Thompson's Palace of the End, both the American female SOLDIER and her army fellows are portrayed as lacking in the 'ethical' and the 'aesthetic.' She is not only rude, disgusting, and ugly looking, but she is equally cheap. The obscene language she uses is not merely employed to depict the 'low' language of soldiers, but it is meant to emphasize their hollow mindedness. All the scenes reported in her monologue are characterized by the dearth of public affection and "smartness". The American female SOLDIER is depicted as a 'sexual animal' where sexuality has pictured her as poor, infantile, and a derisive negative figure. Since public affection and appropriate manners are morally considered supplements, as well as correctives, their absence in the representation of the American female SOLDIER and her fellows, has darkened them, portraying them as sick 'beastly' colonizers who have predetermined intrigued to mongrelize the colonized's nation and transform its people's material and moral conditions and plunder 
their identity of "its vital substance."o The US colonialism is systematically determined to rob the Iraqis of their politico-cultural codes and impose other ones: it is an ideology that aims at substituting the Iraqi sets of values to separate the people from their legacy so that they will be easily lead by the nose!

Conflict of interest statement

The author declared that he has no competing interests.

Statement of authorship

The author has a responsibility for the conception and design of the study. The author has approved the final article.

Acknowledgments

The research worker highly acknowledges his indebtedness to his colleague Assistant Professor Raad Kareem Abs Aun for his insightful discussion and interest in postcolonial drama. Most grateful is the author to all those who have dealt with cultural and postcolonial theories. Nevertheless, the author is equally grateful to the playwright Judith Thompson for her kind suggestions.

${ }^{\mathrm{o}}$ Eagleton, 84.

Hameed, S. M. (2020). Representation of Iraqi prisoners' abuse in Judith Thompson's palace of the end: a politicocultural perspective. International Journal of Linguistics, Literature and Culture, 6(4), 95-102. https://doi.org/10.21744/ijllc.v6n4.909 


\section{References}

Abd-Aun, R. K. (2011). The Representation of the Other in Postcolonial Drama: A Comparative Study in Selected Postcolonial Plays in English and Arabic. An Unpublished PhD. Dissertation, College of Arts, University of Baghdad.

Eagleton, T. (2016). The hubris of culture: and the limits of identity politics. Commonweal, 143(7), 19.

Ellis, B. E. (1991). American Psycho. New York: Random House Digital, Inc.,

Evan, D. (1996). An Introductory Dictionary of Langanian Psychoanalysis, London \&New York: Routledge.

Friedman, S. (2010). The gendered terrain in contemporary theatre of war by women. Theatre Journal, 593-610.

Jones, K. (2008). Judith Thompson's Palace of the End Looks at the Iraq War. Play Bell.

Spencer, J. (Ed.). (2011). Political and protest theatre after 9/11: patriotic dissent. Routledge.

Thompson, J. (2015). Palace of the End. Oberon Books.

Thompson, J. (2016). An E-mail to the Author. 